\title{
Ontogeny of odor-LiCl vs. odor-shock learning: Similar behaviors but divergent ages of functional amygdala emergence
}

\author{
Charlis Raineki, ${ }^{1-4}$ Kiseko Shionoya, $^{3}$ Kristin Sander, $^{3}$ and Regina M. Sullivan ${ }^{1-3}$ \\ ${ }^{1}$ Emotional Brain Institute, Nathan Kline Institute for Psychiatric Research, Child and Adolescent Psychiatry, Child Study Center, \\ New York University Langone Medical Center, Orangeburg, New York 10962, USA; ${ }^{2}$ Department of Zoology, University of \\ Oklahoma, Norman, Oklahoma 73019, USA; ${ }^{3}$ Department of Zoology, University of Oklahoma, Norman, Oklahoma 73019, USA
}

\begin{abstract}
Both odor-preference and odor-aversion learning occur in perinatal pups before the maturation of brain structures that support this learning in adults. To characterize the development of odor learning, we compared three learning paradigms: (1) odor-LiCl (0.3M; $1 \%$ body weight, ip) and (2) odor-1.2-mA shock (hindlimb, 1sec)—both of which consistently produce odor-aversion learning throughout life and (3) odor-0.5-mA shock, which produces an odor preference in early life but an odor avoidance as pups mature. Pups were trained at postnatal day (PN) 7-8, 12-13, or 2324 , using odor-LiCl and two odor-shock conditioning paradigms of odor-0.5-mA shock and odor-1.2-mA shock. Here we show that in the youngest pups (PN7-8), odor-preference learning was associated with activity in the anterior piriform (olfactory) cortex, while odor-aversion learning was associated with activity in the posterior piriform cortex. At PN12-13, when all conditioning paradigms produced an odor aversion, the odor- $0.5-\mathrm{mA}$ shock, odor-1.2-mA shock, and odor-LiCl all continued producing learning-associated changes in the posterior piriform cortex. However, only odor-0.5-mA shock induced learning-associated changes within the basolateral amygdala. At weaning (PN23-24), all learning paradigms produced learning-associated changes in the posterior piriform cortex and basolateral amygdala complex. These results suggest at least two basic principles of the development of the neurobiology of learning: (1) Learning that appears similar throughout development can be supported by neural systems showing very robust developmental changes, and (2) the emergence of amygdala function depends on the learning protocol and reinforcement condition being assessed.
\end{abstract}

Even in utero, infant rats rapidly learn to avoid odors paired with malaise (LiCl) as expressed by learning an odor aversion (Garcia et al. 1966, 1974; Hennessey et al. 1976; Haroutunian and Campbell 1979; Smotherman 1982; Stickrod et al. 1982; Rudy and Cheatle 1983; Kucharski and Spear 1984; Smotherman and Robinson 1985, 1990; Alleva and Calamandrei 1986; Coopersmith et al. 1986; Miller et al. 1990b; Batsell and Best 1992, 1993; Richardson and McNally 2003; Gruest et al. 2004; Shionoya et al. 2006). In contrast to adult odor-LiCl learning, which relies on the amygdala (Touzani and Sclafani 2005), this early-life, odoraversion learning relies on the olfactory bulb until the pup approaches weaning age, when the amygdala is incorporated into the learning circuitry (Shionoya et al. 2006). In contrast, if infant rats receive an odor paired with a moderately painful stimulus (0.5-mA foot or tail shock, or tail pinch) the amygdala appears to be incorporated into this learning circuitry around postnatal day (PN) 10-12 (Sullivan et al. 2000a; Roth and Sullivan 2005; Moriceau and Sullivan 2006; Moriceau et al. 2006). Thus, these data suggest the functional emergence of the amygdala in odoraversion learning depends upon the type of learning paradigm.

Here we expand assessment of the developing pups' odoraversion learning circuit by including the anterior and posterior piriform cortex, which have previously been demonstrated to be important for both pup and adult odor learning (Litaudon et al. 1997; Barkai and Saar 2001; Mouly et al. 2001; Mouly and Gervais 2002; Tronel and Sara 2002; Moriceau and Sullivan 2004;

\footnotetext{
${ }^{4}$ Corresponding author.
}

E-mail craineki@nki.rfmh.org; fax (845) 398-2193.

Article is online at http://www.learnmem.org/cgi/doi/10.1101/lm.977909.
Sevelinges et al. 2004; Wilson et al. 2004; Roth et al. 2006). We also extend the assessment of the development of odor-aversion learning by directly comparing a range of odor-aversion learning paradigms and including different intensities of shock. Haroutunian and Campbell (1979) demonstrated that moderately painful shock could not support aversion learning in neonatal rat pups unless it was delivered intraperitoneally, although higher shock $(>1.0 \mathrm{~mA})$ readily produced an odor aversion in very young pups (Kucharski and Spear 1984; Miller et al. 1990a; Sullivan and Wilson 1995). While lower shock levels are painful to pups (Stehouwer and Campbell 1978; Collier and Bolles 1980; Emerich et al. 1985; Sullivan et al. 2000a), they paradoxically produce an odor preference in pups younger than PN10-12 (Sullivan et al. 1986; Camp and Rudy 1988), apparently due to the amygdala's failure to participate during the conditioning (Sullivan et al. 2000a).

These data suggest that pups have access to at least two neural pathways for odor-aversion learning, although each has a different developmental time course. To test this, we made a direct neurobehavioral comparison of LiCl-induced odor aversion, $1.2-\mathrm{mA}$ shock-induced odor aversion, and the $0.5-\mathrm{mA}$ shock that produces a preference in young pups but an aversion in older pups. We used rats ranging from an age of complete dependence on the mother through an age of independence at weaning. We focused on the amygdala basolateral complex, which is implicated in adult fear conditioning and odor-malaise learning (Bermudez-Rattoni et al. 1986; LeDoux 2000; Batsell and Blankenship 2002; Gale et al. 2004; Holland and Gallagher 2004), and the anterior and posterior piriform cortex, olfactory pathway areas that have previously been implicated in infant odor-aversion and odor-preference learning 
(Moriceau et al. 2006; Roth and Sullivan 2005; Roth et al. 2006) as well as adult odor learning (Ferry and Di Scala 1997; Litaudon et al. 1997; Barkai and Saar 2001; Mouly et al. 2001; Mouly and Gervais 2002; Tronel and Sara 2002; Sevelinges et al. 2004; Wilson et al. 2004; Touzani and Sclafani 2005).

\section{Results}

\section{Malaise associated with $\mathrm{LiCl}$ and 1.2-mA shock}

As illustrated in Figure 1, $\mathrm{LiCl}$ induced gastrointestinal distress (as indicated by diarrhea) in pups at all ages (Davenport 1950; Stern et al. 1969), while 1.2-mA shock only produced gastrointestinal distress in PN7-8 and PN12-13 pups. Of animals receiving 0.5-mA shock, younger pups rarely defecated while PN23-24 pups showed increased defecation of relatively normal consistency and color $\left(F_{(4,27)}=13.000, P<0.0001\right)$.

\section{Odor preference/aversion}

As illustrated in Figure 2, $\mathrm{LiCl}$ and 1.2-mA shock resulted in pups of all ages learning an odor aversion, while $0.5-\mathrm{mA}$ shock switched from producing an odor preference in younger pups to an aversion in older pups (Garcia et al. 1966, 1974; Hennessey et al. 1976; Haroutunian and Campbell 1979; Smotherman 1982; Stickrod et al. 1982; Rudy and Cheatle 1983; Kucharski and Spear 1984; Smotherman and Robinson 1985, 1990; Alleva and Calamandrei 1986; Coopersmith et al. 1986; Miller et al. 1990b; Batsell and Best 1992, 1993; Sullivan and Wilson 1995; Sullivan et al. 2000a; Roth and Sullivan 2001; Richardson and McNally 2003; Gruest et al. 2004; Moriceau and Sullivan 2004; Roth et al. 2006; Shionoya et al. 2006).

\section{PN7-8}

Pairing an odor with 0.5-mA shock induced a preference for that odor, while both odor- $\mathrm{LiCl}$ and odor-1.2-mA shock pups expressed an odor aversion (Fig. 2A). A significant interaction between training and condition was detected $\left(F_{(4,50)}=26.171, P<\right.$ $0.0001)$, and post hoc Fisher test revealed that all paired groups differed from each of the control groups (unpaired and odor). Paired odor-0.5-mA shock pups learned an odor preference, while paired odor-1.2-mA shock and paired odor-LiCl pups learned an odor aversion.

\section{PN12-13}

All conditioning procedures produced an odor aversion (Fig. 2B). No significant interaction between training and condition was detected $\left(F_{(4,45)}=1.224\right)$. However, a significant main effect for condition was detected $\left(F_{(2,45)}=60.765, P<0.0001\right)$. Post hoc Fisher test revealed that all paired groups differed from each of the control groups (unpaired and odor).

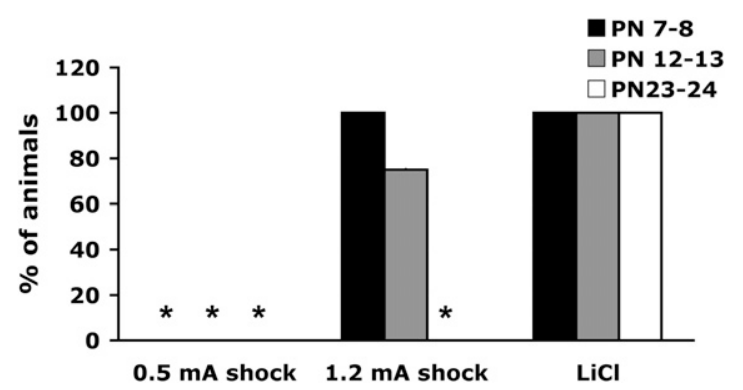

Figure 1. Gastrointestinal distress (diarrhea) in 0.5-mA shock-, 1.2-mA shock-, and LiCl-paired pups as a measure of malaise. ${ }^{*} P<0.05$, significant difference from each group.
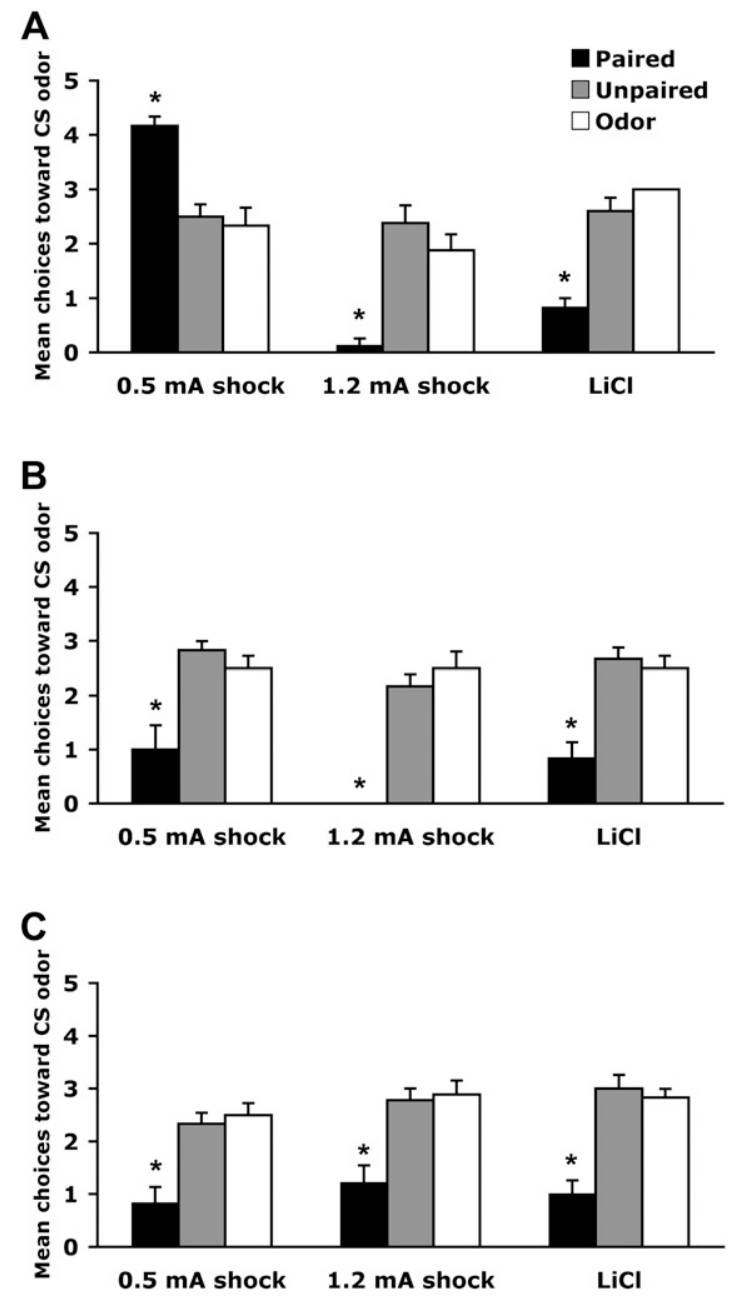

Figure 2. Mean ( \pm SEM) number of choices toward conditioned odor in the $\mathrm{Y}$-maze test (total of five trails) for odor-0.5-mA shock, odor-1.2-mA shock, and odor-LiCl conditioning at PN7-8 (A), PN12-13 (B), and PN2324 (C). ${ }^{\star} P<0.05$, significant difference from each control group.

\section{PN23-24}

All conditioning procedures produced an odor aversion (Fig. 2C). No significant interaction between training and condition was detected $\left(F_{(4,54)}=0.248\right)$. However, a significant main effect for condition was detected $\left(F_{(2,54)}=39.939, P<0.0001\right)$. Post hoc Fisher test revealed that all paired groups differed from each of the control groups (unpaired and odor).

\section{Anterior piriform cortex}

As illustrated in Figure 4, the anterior piriform cortex, which is part of the olfactory cortex (Fig. 3A), showed learning-associated changes only in pups that learned an odor preference (PN7-8 odor-0.5-mA shock).

\section{PN7-8}

Pairing an odor with 0.5-mA shock induced enhancement of ${ }^{14} \mathrm{C}$ 2-deoxyglucose (2-DG) uptake within the anterior piriform cortex, although no learning-induced changes were detected in both odor-LiCl and odor-1.2-mA shock conditioning groups (Fig. 4A). A significant interaction between training and condition was detected $\left(F_{(4,41)}=2.514, P<0.05\right)$, and post hoc Fisher test revealed that the odor-0.5-mA shock paired group differed from the control groups (unpaired and odor). 

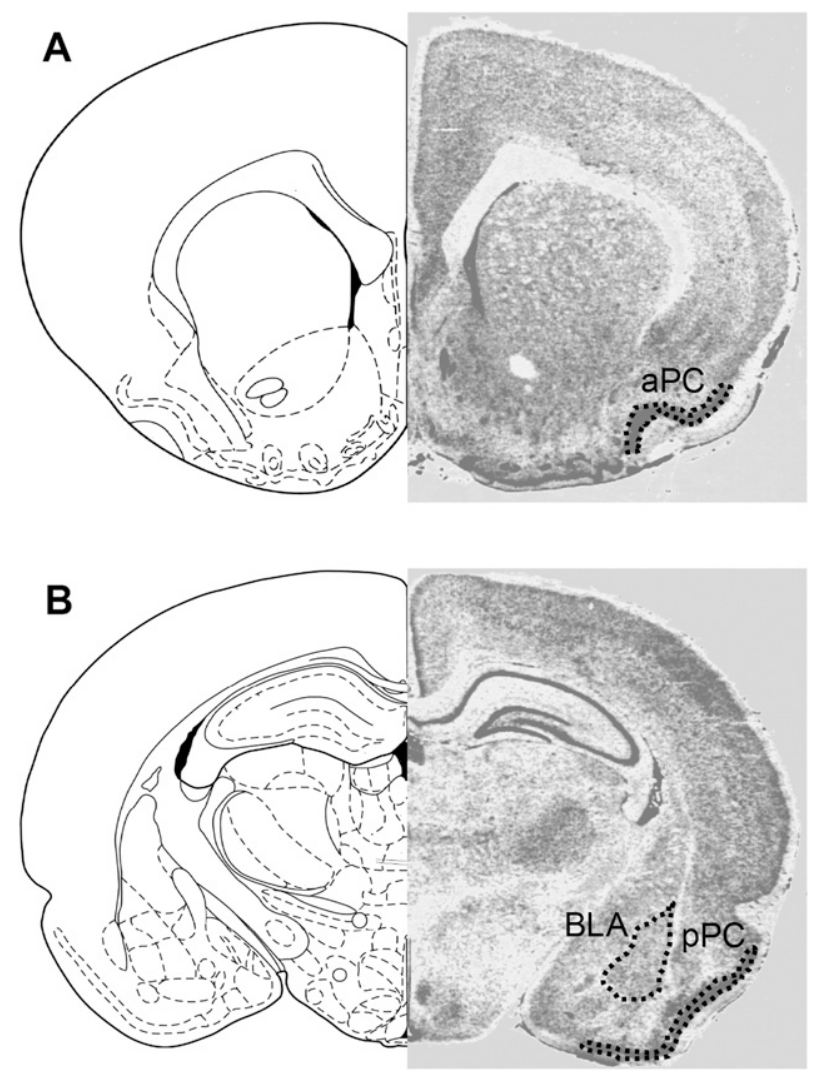

Figure 3. Pseudocolor 2-DG autoradiograph with the corresponding coronal brain section images from Paxinos and Watson (1986). The individual areas are outlined and labeled in the right images to indicate where optical densitomentric measurements were made in this study. aPC indicates anterior piriform cortex $(A) ; \mathrm{PPC}$, posterior piriform cortex $(B)$; and BLA, basolateral complex of amygdala (B). (Image reprinted with permission from Elsevier (C1986.)

PN12-13

None of the conditioning procedures produced learning-induced modifications of 2-DG uptake within the anterior piriform cortex (Fig. 4B). No significant interaction between training and condition was detected $\left(F_{(4,42)}=0.605\right)$.

PN23-24

None of the conditioning procedures produced learning-induced modifications of 2-DG uptake within the anterior piriform cortex (Fig. 4C). No significant interaction between training and condition was detected $\left(F_{(4,44)}=0.622\right)$.

\section{Posterior piriform cortex}

As shown in Figure 5 , the posterior piriform cortex, which is part of the olfactory cortex (Fig. 3B), showed learning-associated changes only in pups that learned an odor aversion.

\section{PN7-8}

Pairing an odor with both 1.2-mA shock and $\mathrm{LiCl}$ induced enhancement of 2-DG uptake within the posterior piriform cortex, although no learning-induced changes were detected in odor-0.5mA shock (Fig. 5A). A significant interaction between training and condition was detected $\left(F_{(4,40)}=5.868, P<0.001\right)$, and post hoc Fisher test revealed that odor-1.2-mA shock and odor- $\mathrm{LiCl}$ paired groups differed from each of the control groups (unpaired and odor).

\section{PN12-13}

All conditioning procedures produced learning-induced enhancement of 2-DG uptake within the posterior piriform cortex (Fig. $5 \mathrm{~B})$. No significant interaction between training and condition was detected $\left(F_{(4,44)}=0.330\right)$. However, a significant main effect for condition was detected $\left(F_{(2,44)}=16.262, P<0.0001\right)$. Post hoc Fisher test revealed that all paired groups differed from each of the control groups (unpaired and odor).

\section{PN23-24}

All conditioning procedures produced learning-induced enhancement of 2-DG uptake within the posterior piriform cortex (Fig. $5 C)$. No significant interaction between training and condition was detected $\left(F_{(4,45)}=0.435\right)$. However, a significant main effect for condition was detected $\left(F_{(2,45)}=35.593, P<0.0001\right)$. Post hoc Fisher test revealed that all paired groups differed from each of the control groups (unpaired and odor).

\section{Basolateral amygdala complex}

As shown in Figure 6, the basolateral complex of the amygdala, an area associated with plasticity in adult fear conditioning and adult odor-LiCl learning (Fig. 3B), showed learning-induced changes at PN12-13 only for odor-0.5-mA shock pups and for all conditioning procedures in weanling pups (PN23-24).
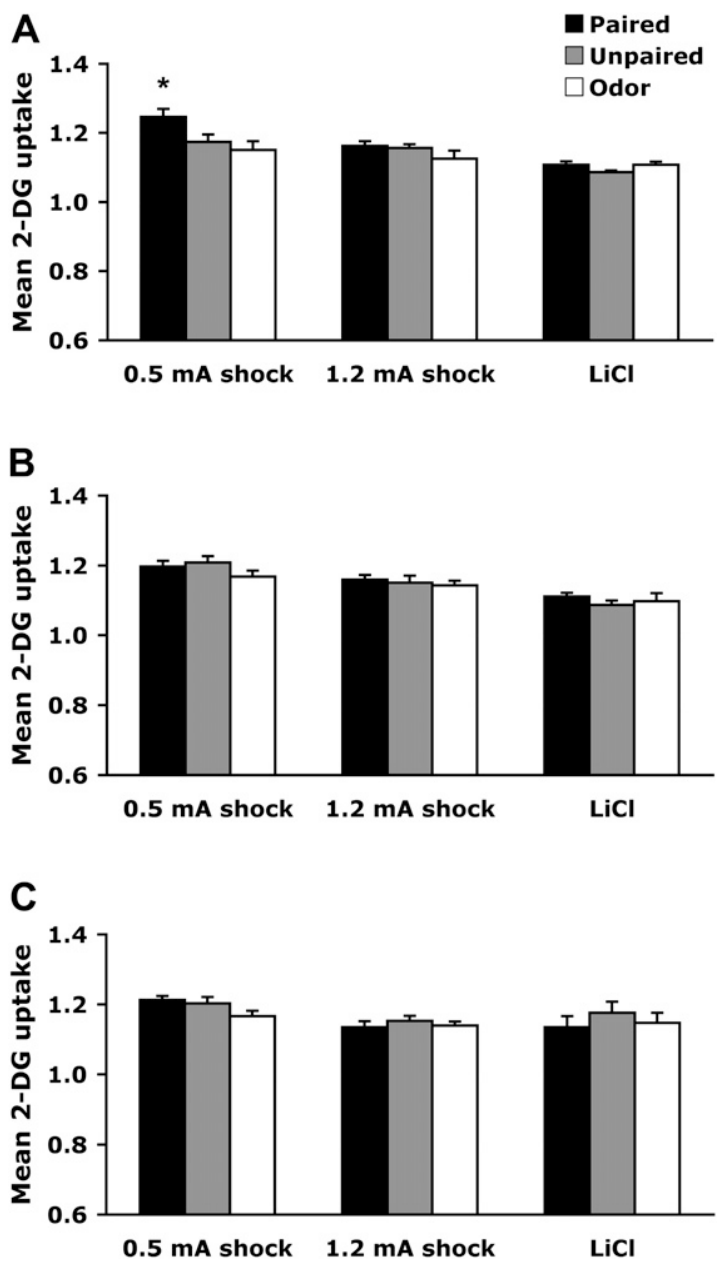

Figure 4. Mean ( $\pm \mathrm{SEM}$ ) relative anterior piriform cortex 2-DG uptake during odor-0.5-mA shock, odor-1.2-mA shock, and odor-LiCl conditioning at PN7-8 $(A)$, PN12-13 $(B)$, and PN23-24 (C). ${ }^{*} P<0.05$, significant difference from each control group. 


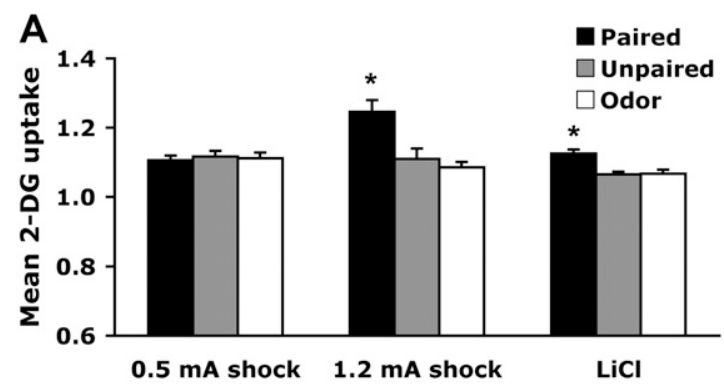

B
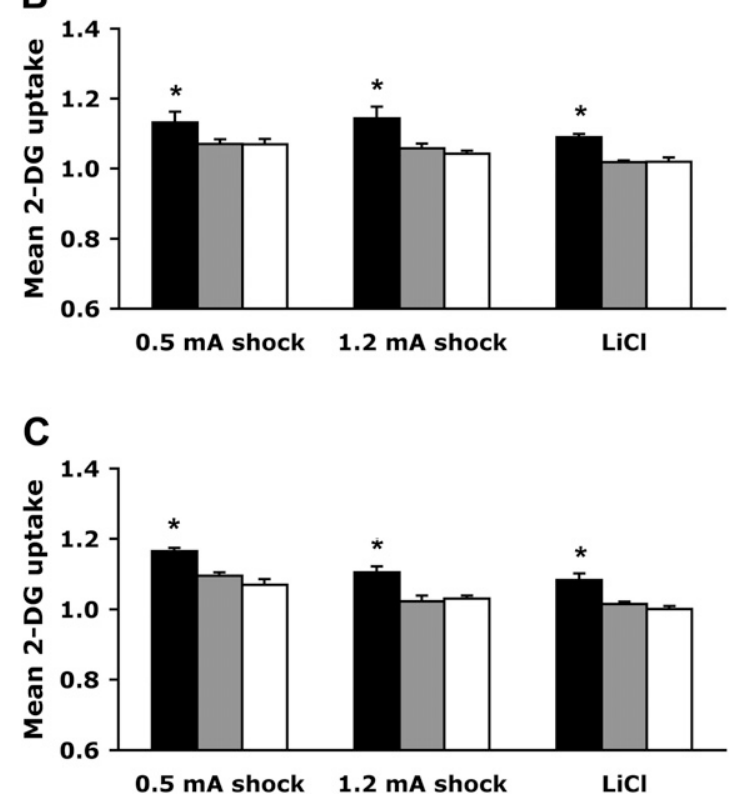

Figure 5. Mean ( \pm SEM) relative posterior piriform cortex 2-DG uptake during odor-0.5-mA shock, odor-1.2-mA shock, and odor-LiCl conditioning at PN7-8 $(A)$, PN12-13 $(B)$, and PN23-24 (C). ${ }^{*} P<0.05$, significant difference from each control group.

\section{PN7-8}

None of the conditioning procedures produced learning-induced enhancement of 2-DG uptake within the basolateral amygdala complex (Fig. 6A). No significant interaction between training and condition was detected $\left(F_{(4,42)}=0.940\right)$.

\section{PN12-13}

Pairing an odor with 0.5-mA shock induced enhancement of 2-DG uptake within the basolateral amygdala complex, although no learning-induced changes were detected in either odor-LiCl or odor-1.2-mA shock (Fig. 6B). A significant interaction between training and condition was detected $\left(F_{(4,43)}=4.494, P<0.004\right)$, and post hoc Fisher test revealed that the odor-0.5-mA shock paired group differed from the control groups (unpaired and odor).

\section{PN23-24}

All conditioning procedures produced learning-induced enhancement of 2-DG uptake within the basolateral amygdala complex (Fig. 6C). A significant interaction between training and condition was detected $\left(F_{(4,45)}=4.939, P<0.002\right)$, and post hoc Fisher test revealed that all paired groups differed from each of the control groups (unpaired and odor).

\section{Discussion}

The present results suggest that pups have at least two neural circuits for odor-aversion learning, with access to one during early life (olfactory bulb-posterior piriform cortex), a transitional period with access to both, and access to another at weaning (posterior piriform cortex-basolateral amygdala complex). It is noteworthy that pups' odor-aversion expression at testing (Y-maze) looks similar throughout development, yet the underlying neural circuitry changes dramatically. These data indicate that similar appearing behaviors during different stages of development cannot be assumed to be supported by the same neural circuitry.

\section{Development of $\mathrm{LiCl}$ learning}

Odor-malaise learning has been shown in fetal rats and throughout development (Hennessey et al. 1976; Rudy and Cheatle 1977, 1983; Smotherman 1982; Stickrod et al. 1982; Smotherman and Robinson 1985; Alleva and Calamandrei 1986; Coopersmith et al. 1986; Molina et al. 1986; Hoffmann et al. 1987, 1990; Miller et al. 1990b; Hunt et al. 1991; Richardson and McNally 2003; Gruest et al. 2004; Shionoya et al. 2006). Since odor-malaise learning occurs in the fetal rat well before amygdala neural development (Berdel et al. 1997; Morys et al. 1999; Berdel and Morys 2000), it is not surprising that pups use a neural pathway distinct from that of
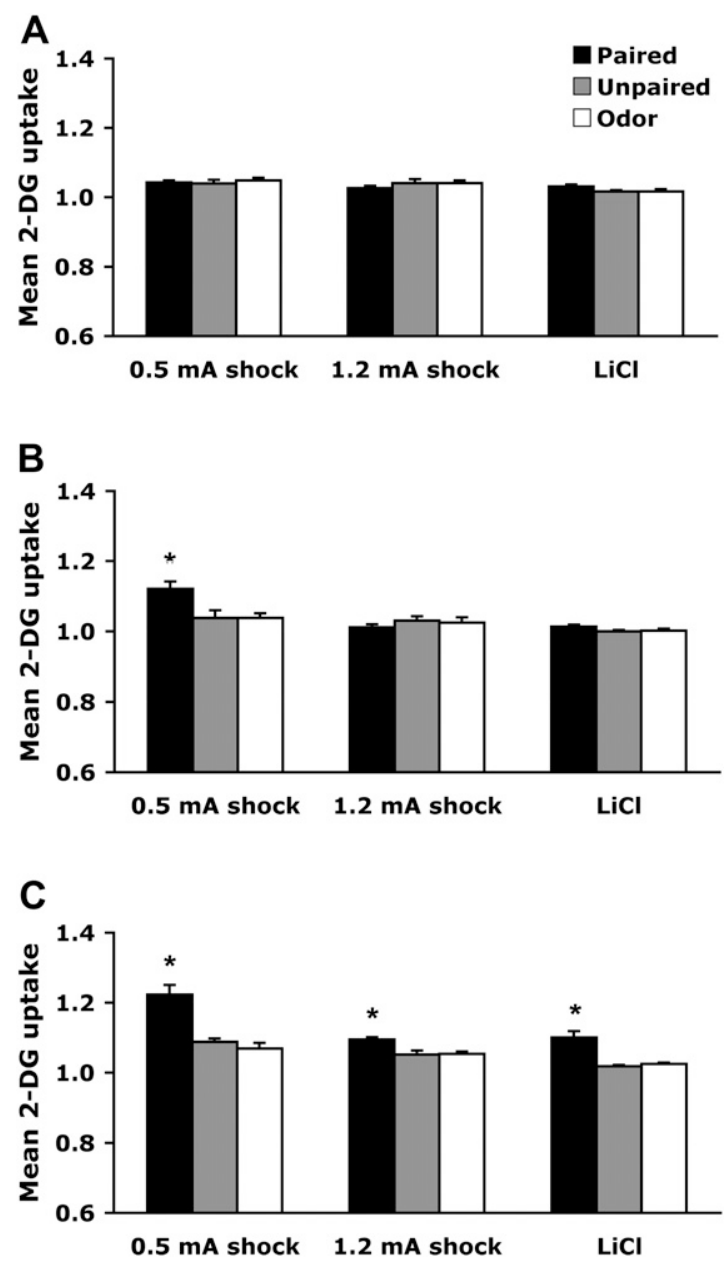

Figure 6. Mean ( \pm SEM) relative amygdala basolateral complex 2-DG uptake during odor-0.5-mA shock, odor-1.2-mA shock, and odor- $\mathrm{LiCl}$ conditioning at PN7-8 $(A)$, PN12-13 $(B)$, and PN23-24 (C). ${ }^{*} P<0.05$, significant difference from each control group. 
the adult, which requires the amygdala (Bermudez-Rattoni et al. 1986; Ferry and Di Scala 1997; Touzani and Sclafani 2005).

We propose that the higher 1.2-mA shock supports learning through malaise, as was originally suggested by Haroutunian and Campbell (1979). This notion is supported by (1) the ability of both $\mathrm{LiCl}$ and $1.2-\mathrm{mA}$ shock, but not $0.5-\mathrm{mA}$ shock, to cause diarrhea in pups (Fig. 1; Davenport 1950; Stern et al. 1969), and (2) the fact that the neural correlates of learning align for $\mathrm{LiCl}$ and 1.2-mA shock, but not 0.5-mA shock, in young pups (Table 1).

\section{Development of fear conditioning}

Our previous work indicates that amygdala-dependent fear conditioning emerges around PN10-12 and is blocked by temporary suppression of the amygdala (muscimol) (Sullivan et al. 2000a; Moriceau and Sullivan 2006). These results not only are replicated by the present work but also are extended to show the continued involvement of the amygdala in weanling aged animals-a finding that is consistent with adult fear conditioning literature about the amygdala (Fanselow and LeDoux 1999; Davis 2000; LeDoux 2000; Otto et al. 2000; Gale et al. 2004; Ponnusamy et al. 2007).

\section{Anterior and posterior piriform cortex}

The anterior and posterior piriform cortices are distinct structures based on both physiological and anatomical assessment, with the anterior more strongly influenced by olfactory bulb input and the posterior more heavily influenced by other limbic structures (including the amygdala) and intracortical connectivity (Swanson and Petrovich 1998; Wilson and Stevenson 2003). Previous data on infant odor learning indicate that the olfactory bulb exhibits robust learning-associated changes in early life, regardless of pups learning an odor preference or odor aversion (Sullivan and Leon 1986; Wilson et al. 1987; Sullivan et al. 1990; Woo et al. 1996; McLean et al. 1999; Yuan et al. 2003; Moriceau and Sullivan 2006; Roth et al. 2006). The role of the olfactory bulb changes with development since older pups and adults do not usually show odor learning-induced changes in this brain area (Hamrick et al. 1993; Woo et al. 1996; Sevelinges et al. 2007). The age at which olfactory bulb early-life learning occurs depends on the type of learning, with odor-malaise learning depending on the olfactory bulb until a later age compared with fear conditioning (Sullivan and Wilson 1995; Moriceau and Sullivan 2004; Shionoya et al. 2006). This finding, combined with the subsequent piriform cortex data, may suggest that the olfactory bulb indicates an odor is important and relies on the piriform cortex to code the hedonic value, although this has not been directly assessed.

Our piriform cortex data aligns odor preference with the anterior piriform and odor aversion with the posterior piriform (Roth and Sullivan 2005; Moriceau et al. 2006; Roth et al. 2006). These data are consistent with the important role of the adult piriform cortex in olfactory conditioning (Litaudon et al. 1997; Barkai and Saar 2001; Mouly et al. 2001; Mouly and Gervais 2002; Tronel and Sara 2002; Sevelinges et al. 2004, 2007; Wilson et al. 2004). However, the specific roles of the anterior and posterior piriform in preference and aversion learning are not consistent with the adult literature, where both have been found important for learning (Hasselmo and Barkai 1995; Litaudon et al. 1997; Barkai and Saar 2001; Haberly 2001; Mouly et al. 2001; Tronel and Sara 2002; Sevelinges et al. 2004; Wilson et al. 2004). It appears as though the anterior piriform cortex is involved in sensory processes and simple forms of memory like habituation or perceptual learning (Wilson 1997, 2000; Kadohisa and Wilson 2006), while the posterior piriform cortex expands on this processing and is involved in more complex learning processes and integration of information from other sensory modalities and previous experience (Litaudon et al. 1997, 2003; Chabaud et al. 1999, 2000; Haberly 2001; Mouly et al. 2001; Sevelinges et al. 2004; Gottfried et al. 2006; Kadohisa and Wilson 2006; Calu et al. 2007). Consequently, it is difficult to reconcile our infant piriform results with the adult literature, and further work on the infant piriform is required.

\section{Amygdala basolateral complex}

The amygdala receives significant olfactory information from the olfactory bulb and posterior piriform cortex, with minor input from the anterior piriform cortex, with all odor input eventually converging on the amygdala's cortical nucleus and on to the amygdala's basolateral complex (Krettek and Price 1978; Ottersen 1982; Luskin and Price 1983; Savander et al. 1996; McDonald 1998; Swanson and Petrovich 1998; Sah et al. 2003). Several lines of evidence indicate that in adult rats, the amygdala plays a crucial role in both fear conditioning and odor-LiCl conditioning (Bermudez-Rattoni et al. 1986; Ferry and Di Scala 1997; LeDoux 2000; Gale et al. 2004; Touzani and Sclafani 2005). It should be noted that the basolateral complex of the amygdala is essential for odormalaise learning, although results are inconsistent for tastemalaise learning (Nachman and Ashe 1974; Burt and Smotherman 1980; Bermudez-Rattoni et al. 1986; Dunn and Everitt 1988; Yamamoto and Fujimoto 1991; Kesner et al. 1992; Sakai and Yamamoto 1999; Bahar et al. 2004; Touzani and Sclafani 2005; Wilkins and Bernstein 2006).

The role of the amygdala in pup odor-shock and odor-LiCl learning indicates distinct age differences, with the amygdala becoming incorporated into odor-0.5-mA shock conditioning by PN10-12 (Sullivan et al. 2000a; Roth and Sullivan 2005; Moriceau and Sullivan 2006; Moriceau et al. 2006), but delayed for odor-LiCl learning closer to weaning. These results suggest that infant odoraversion learning with higher levels of shock (1.2 mA) causing gastrointestinal distress (i.e., diarrhea) only in young pups probably

Table 1. Behavior (Y-maze) and conditioned neural activity (2-DG uptake) in odor-0.5-mA shock-, odor-1.2-mA shock-, and odor-LiCl-paired pups during development

\begin{tabular}{|c|c|c|c|c|c|c|}
\hline & Conditioning & Behavior & $\begin{array}{l}\text { Olfactory } \\
\text { bulb }\end{array}$ & $\begin{array}{l}\text { Anterior piriform } \\
\text { cortex }\end{array}$ & $\begin{array}{l}\text { Posterior piriform } \\
\text { cortex }\end{array}$ & $\begin{array}{c}\text { Basolateral complex } \\
\text { of amygdala }\end{array}$ \\
\hline PN7-8 & $\begin{array}{l}0.5-\mathrm{mA} \text { shock } \\
1.2-\mathrm{mA} \text { shock } \\
\mathrm{LiCl}\end{array}$ & $\begin{array}{l}\text { Preference } \\
\text { Aversion } \\
\text { Aversion }\end{array}$ & $\begin{array}{l}\sqrt{ } \\
\sqrt{ } \\
\sqrt{ }\end{array}$ & $\sqrt{ }$ & $\begin{array}{l}\sqrt{ } \\
\sqrt{ }\end{array}$ & \\
\hline PN12-13 & $\begin{array}{l}0.5-\mathrm{mA} \text { shock } \\
\text { 1.2-mA shock } \\
\mathrm{LiCl}\end{array}$ & $\begin{array}{l}\text { Aversion } \\
\text { Aversion } \\
\text { Aversion }\end{array}$ & $\sqrt{ }$ & & $\begin{array}{l}\sqrt{ } \\
\sqrt{ } \\
\sqrt{ }\end{array}$ & $\sqrt{ }$ \\
\hline PN23-24 & $\begin{array}{l}0.5-\mathrm{mA} \text { shock } \\
\text { 1.2-mA shock } \\
\mathrm{LiCl}\end{array}$ & $\begin{array}{l}\text { Aversion } \\
\text { Aversion } \\
\text { Aversion }\end{array}$ & & & $\begin{array}{l}\sqrt{ } \\
\sqrt{ } \\
\sqrt{ }\end{array}$ & $\begin{array}{l}\sqrt{ } \\
\sqrt{ } \\
\sqrt{ }\end{array}$ \\
\hline
\end{tabular}

The olfactory bulb data are from Sullivan and Wilson (1995), Moriceau and Sullivan (2004), and Shionoya et al. (2006). 
uses the same circuit as odor-malaise learning in early life. However, this odor-1.2-mA learning uses the fear conditioning circuit at weaning.

\section{Ecological significance}

During early life, when infant rats are confined to the nest, they rapidly learn to prefer an odor when it is paired with pain $(0.5-\mathrm{mA}$ shock or tail pinch) (Haroutunian and Campbell 1979; Sullivan et al. 1986; Camp and Rudy 1988). This paradoxical learning presumably occurs because pups must learn the maternal odor, which is then used to approach the mother and nipple attach (Hofer et al. 1976; Pedersen et al. 1982; Leon 1992; Polan and Hofer 1999). Therefore, pups' survival is dependent on odorapproach learning, suggesting that evolutionary pressure may have selected for a neural circuit to ensure pups only learn to approach their caregiver, regardless of the quality of care received (Bowlby 1965; Hofer and Sullivan 2001). While this odor-0.5-mA shock conditioning begins to produce fear learning at PN10-12, fear conditioning is blocked and the early-life, odor-preference learning is extended via suppression of the amygdala when the mother is present (Moriceau and Sullivan 2006). A similar learning constraint exists with odor-LiCl and taste-LiCl learning. Specifically, if pups nurse during odor- $\mathrm{LiCl}$ conditioning, they develop a preference for the odor (Shionoya et al. 2006), while taste- $\mathrm{LiCl}$ avoidance learning is blocked (Martin and Alberts 1979; Gubernick and Alberts 1984; Melcer et al. 1985; Kehoe and Blass 1986).

\section{Implications for understanding the ontogeny of learning}

Our data suggest at least two basic principles concerning the development of the neurobiology of learning: (1) Learning that appears similar throughout development can be supported by neural systems showing very robust developmental changes, and (2) the functional emergence of the amygdala depends upon the learning protocol and reinforcement condition being assessed. In odor-malaise conditioning (1.2-mA shock and $\mathrm{LiCl}$ ), the basolateral complex of amygdala is incorporated into the neural circuit close to weaning age. On the other hand, the basolateral complex of the amygdala is incorporated early (PN12-13) in fear conditioning (odor-0.5-mA shock).

\section{Materials and Methods}

\section{Subjects}

We used male and female Long-Evans rat pups born and bred in our colony at the University of Oklahoma (originally from Harlan Laboratory Animals, Houston, TX). Pup ages were PN7-8 (pups are mostly confined to the nest), PN12-13 (pups are venturing outside the nest but still require the mother for survival), and PN23-24 (weaning age). Animals were housed in polypropylene cages ( $34 \times$ $29 \times 17 \mathrm{~cm}$ ) with an abundant amount of Aspen wood shavings for nest building and were kept in a $20^{\circ} \mathrm{C}$ environment with a 12:12 light cycle. Food and water were available ad libitum. The day of birth was considered PNO, and the litters were culled to 12 pups (six males and six females) on PN1. No more than one male and one female from a litter were used in each experimental condition. The University of Oklahoma Institutional Animal Care and Use Committee, which follows guidelines from the National Institutes of Health, approved all animal care and experimental procedures.

\section{Odor-shock conditioning}

Pups were randomly assigned to one of the following classical conditioning groups: (1) paired odor-0.5-mA or odor-1.2-mA shock, (2) unpaired odor-shock, and (3) odor. Training occurred in $27^{\circ} \mathrm{C}$ (weaning) to $30^{\circ} \mathrm{C}$ (infants) $\pm 0.1^{\circ} \mathrm{C}$ environment with temperature at the start of training maintained throughout conditioning. Pups were trained in individual 600-mL (PN7-8 and PN12-13) or 1200-mL (PN23-24) beakers and were given a 10min adaptation period to recover from experimental handling. During a 45-min training session, pups received 11 presentations of a $30-\mathrm{sec}$ peppermint odor and a $1-\mathrm{sec}, 0.5-\mathrm{mA}$ or $1.2-\mathrm{mA}$ hindlimb shock, with an intertrial interval of $4 \mathrm{~min}$. The odor (peppermint, McCormick \& Co Inc., complex natural extract in $89 \%$ alcohol) was delivered by a flow dilution olfactometer $(2 \mathrm{~L} /$ min flow rate) at a concentration of 1:10 peppermint vapor. Paired odor-shock pups received 11 pairings of the 30-sec odor with shock overlapping during the last $1 \mathrm{sec}$ of the odor presentation. Unpaired odor-shock pups received the shock 2 min after each 30sec odor presentation. Odor pups received only the peppermint odor presentations (Sullivan et al. 2000a,b; Roth and Sullivan 2001, 2003; Moriceau and Sullivan 2004, 2006). After training, pups were returned to the home cage until testing the next day.

\section{Odor-LiCl conditioning}

Pups were randomly assigned to one of the following conditioning groups: (1) paired odor-LiCl, (2) unpaired, and (3) odor. Training occurred in $27^{\circ} \mathrm{C}$ (weaning) to $30^{\circ} \mathrm{C}$ (infants) $\pm 0.1^{\circ} \mathrm{C}$ environment with temperature at the start of training maintained throughout conditioning. Pups were trained in opaque Plexiglas chambers (30.5-cm width $\times 45.5$-cm length $\times 45-\mathrm{cm}$ height) and were given a 10-min adaptation period to recover from experimental handling. Paired odor-LiCl pups had $\mathrm{LiCl}(0.3 \mathrm{M})$ of $1 \%$ of body weight injected $5 \mathrm{~min}$ after the start the 30 -min odor presentation. Unpaired pups were injected with $\mathrm{LiCl} 5 \mathrm{~min}$ after being placed in the training box. Odor pups were exposed to odor and injected with isotonic saline (1\% body weight) $5 \mathrm{~min}$ after the start of the peppermint odor presentations. The 30-min odor was presented on a Kim-wipe ( $25 \mu \mathrm{L}$ of peppermint) and placed beneath the metal mesh floor. A new odor was replaced halfway through conditioning (Shionoya et al. 2006). After training, pups were returned to the home cage until testing the next day.

\section{Pup behavioral testing}

The day following conditioning, a Y-maze was used to assess pups' expression of an odor preference or aversion. The test requires pups to choose between two arms of a Plexiglas Y-maze (start box: 8.5 -cm width $\times 10$-cm length $\times 8$-cm height; choice arms: $8.5 \times$ $24 \times 8 \mathrm{~cm})$, one containing the peppermint odor $(20 \mu \mathrm{L}$ of peppermint odor on a Kim-wipe placed at the end of the alley) and the other a familiar odor $(20 \mathrm{~mL}$ of clean Aspen shavings in a petri dish). Pups were placed in the start box (direction was counterbalanced); after $5 \mathrm{sec}$, the door to each alley was opened, at which time the pups were given 60 sec to choose an arm. A response was considered a choice when a pup's entire body was past the entrance to the alley. Each pup received five sequential trials, and between trials, the pup was placed in a holding cage for $10 \mathrm{sec}$ and the floor was cleaned with water and dried. Observations of each pup were made blind to the training condition.

\section{2-DG autoradiography}

Half the pups in each training condition were used to assess the neural substrate associated with learning. Pups were injected with ${ }^{14} \mathrm{C}$ 2-deoxyglucose (2-DG; $20 \mu \mathrm{Ci} / 100 \mathrm{~g}$, sc) $5 \mathrm{~min}$ prior to conditioning. Immediately after training, pups were decapitated and their brains quickly removed, frozen in 2-methylbutane $\left(-45^{\circ} \mathrm{C}\right)$, and stored in $\mathrm{a}-70^{\circ} \mathrm{C}$ freezer. For analysis, brains were sectioned $(20 \mu \mathrm{m})$ in $\mathrm{a}-20^{\circ} \mathrm{C}$ cryostat, with every second section placed on a cover slip and exposed for $5 \mathrm{~d}$ along with ${ }^{14} \mathrm{C}$ standards $\left({ }^{14} \mathrm{C}\right.$ standards $10 \times 0.02 \mathrm{mCi}$, American Radiolabeled Chemicals, Inc.) to X-ray film (DiRocco and Hall 1981; Coopersmith and Leon 1986; Sullivan and Wilson 1995). The autoradiographs were analyzed using National Institutes of Health image software that allows pseudocolor imaging and quantitative optical densitometry. The anterior and posterior piriform cortex and basolateral amygdala complex were identified by counterstaining sections with cresyl violet and by making a template of those brain areas, which were then placed over the autoradiograph's enlarged image to guide optical density measurements. The 2-DG uptake was expressed relative to 2-DG uptake in the corpus callosum (which 
did not vary with conditioning group) to control for differences in section thickness and exposure (Sullivan et al. 2000a). All measurements were done blind to the experimental conditions.

\section{Statistical analysis}

For all experiments, comparisons were made between groups using two-way ANOVA (training and condition effect) followed by post hoc Fisher test.

\section{Acknowledgments}

This work was funded by grants NICHD-HD33402, NSF IOB0544406, and Oklahoma Center for Science and Technology OCAST to R.M.S.; CAPES (Brazil) to C.R.; and Reiken funds (Japan) to K.S.

\section{References}

Alleva, E. and Calamandrei, G. 1986. Odor-aversion leaning and retention span in neonatal mouse pups. Behav. Neural Biol. 46: 348-357.

Bahar, A., Dorfman, N., and Dudai, Y. 2004. Amygdala circuits required for either consolidation or extinction of taste aversion memory are not required for reconsolidation. Eur. J. Neurosci. 19: 1115-1118.

Barkai, E. and Saar, D. 2001. Cellular correlates of olfactory learning in the rat piriform cortex. Rev. Neurosci. 12: 111-120.

Batsell, W.R. and Best, M.R. 1992. Variations in the retention interval of taste aversions: Evidence for retrieval competition. Anim. Learn. Behav. 20: $146-159$.

Batsell, W.R. and Best, M.R. 1993. One bottle too many? Method of testing determines the detection of overshadowing and retention of taste aversions. Learn. Behav. 21: 154-158.

Batsell, W.R. and Blankenship, A.G. 2002. Beyond potentiation: Synergistic conditioning in flavor-aversion learning. Brain Mind 3: 383-408.

Berdel, B. and Morys, J. 2000. Expression of calbindin-D28k and parvalbumin during development of rat's basolateral amygdaloid complex. Int. J. Dev. Neurosci. 18: 501-513.

Berdel, B., Morys, J., and Maciejewska, B. 1997. Neuronal changes in the basolateral complex during development of the amygdala of the rat. Int J. Dev. Neurosci. 15: 755-765.

Bermudez-Rattoni, F., Grijalva, C.V., Kiefer, S.W., and Garcia, J. 1986. Flavorillness aversions: The role of the amygdala in the acquisition of tastepotentiated odor aversions. Physiol. Behav. 38: 503-508.

Bowlby, J. 1965. Attachment. Basic Books, New York.

Burt, G.S. and Smotherman, W.P. 1980. Amygdalectomy induced deficits in conditioned taste aversion: Possible pituitary-adrenal involvement. Physiol. Behav. 24: 651-655.

Calu, D.J., Roesch, M.R., Stalneker, T.A., and Schoenbaum, G. 2007. Associative encoding in posterior piriform cortex during odor discrimination and reversal learning. Cereb. Cortex 17: 1342-1349.

Camp, L.L. and Rudy, J.W. 1988. Changes in the categorization of appetitive and aversive events during postnatal development of the rat. Dev. Psychobiol. 21: 25-42.

Chabaud, P., Ravel, N., Wilson, D.A., and Gervais, R. 1999. Functional coupling in rat central olfactory pathways: A coherence analysis. Neurosci. Lett. 276: 17-20.

Chabaud, P., Ravel, N., Wilson, D.A., Mouly, A.M., Vigouroux, M., Farget, V., and Gervais, R. 2000. Exposure to behaviorally relevant odour reveals differential characteristics in rat central olfactory pathways as studied through oscillatory activities. Chem. Senses 25: 561-573.

Collier, A.C. and Bolles, R.C. 1980. The ontogenesis of defensive reactions to shock in preweanling rats. Dev. Psychobiol. 13: 141-150.

Coopersmith, R. and Leon, M. 1986. Enhanced neural responses by adult rats odors experienced early in life. Brain Res. 371: 400-403.

Coopersmith, R., Lee, S., and Leon, M. 1986. Olfactory bulb responses after odor aversion learning by young rats. Brain Res. 389: 271-277.

Davenport, V.D. 1950. Distribution of parenterally administered lithium in plasma, brain and muscle of rats. Am. J. Physiol. 163: 633-641.

Davis, M. 2000. The role of the amygdala in conditioned and unconditioned fear and anxiety. In The amygdala (ed. J.P. Aggleton), pp. 213-287. Oxford University Press, New York.

DiRocco, R.J. and Hall, W.G. 1981. Metabolic neural mapping in neonatal rats. J. Neurosci. Res. 6: 13-19.

Dunn, L.T. and Everitt, B.J. 1988. Double dissociations of the effects of amygdala and insular cortex lesions on conditioned taste aversion passive avoidance, and neophobia in the rat using the excitotoxin ibotenic acid. Behav. Neurosci. 102: 3-23.

Emerich, D.F., Scalzo, F.M., Enters, E.K., Spear, N.E., and Spear, L.P. 1985. Effects of 6-hydroxydopamine-induced catecholamine depletion on shockprecipitated wall climbing of infant rat pups. Dev. Psychobiol. 18: 215-227.
Fanselow, M.S. and LeDoux, J.E. 1999. Why we think plasticity underlying pavlovian fear conditioning occurs in the basolateral amygdala. Neuron 23: 229-232.

Ferry, B. and Di Scala, G. 1997. Bicuculline administration into basolateral amygdala facilitates trace conditioning of odor aversion in the rat. Neurobiol. Learn. Mem. 67: 80-83.

Gale, G.D., Anagnostaras, S.G., Godsil, B.P., Mitchell, S., Nozawa, T., Sage, J.R., Wiltgen, B., and Fanselow, M.S. 2004. Role of the basolateral amygdala in the storage of fear memories across the adult lifetime of rats. J. Neurosci. 24: 3810-3815.

Garcia, J., Ervin, F.R., and Koelling, R.A. 1966. Learning with prolonged delay of reinforcement. Psychon. Sci. 5: 121-122.

Garcia, J.D., Yang, M.G., Wang, J.H., and Belo, P.S. 1974. Translocation and fluxes of mercury in neonatal and maternal rats treated with methyl mercuric chloride during gestation. Proc. Soc. Exp. Biol. 147: 224-231.

Gottfried, J.A., Winston, J.S., and Dolan, R.J. 2006. Dissociable codes of odor quality and odorant structure in human piriform cortex. Neuron 49: 467-479.

Gruest, N., Richer, P., and Hars, B. 2004. Emergence of long-term memory for conditioned aversion in the rat fetus. Dev. Psychobiol. 44: 189-198.

Gubernick, D.J. and Alberts, J.R. 1984. A specialization of taste-aversion learning during suckling and its weaning-association transformation. Dev. Psychobiol. 17: 613-628.

Haberly, L.B. 2001. Parallel-distributed processing in olfactory cortex: New insights from morphological and physiological analysis of neuronal circuitry. Chem. Senses 26: 551-576.

Hamrick, W.D., Wilson, D.A., and Sullivan, R.M. 1993. Neural correlates of memory for odor detection conditioning in adult rats. Neurosci. Lett. 163: $36-40$.

Haroutunian, V. and Campbell, B.A. 1979. Emergence of interoceptive and exteroceptive control of behavior in rats. Science 205: 927-929.

Hasselmo, M.E. and Barkai, E. 1995. Cholinergic modulation of activitydependent synaptic plasticity in the piriform cortex and associative memory function in a network biophysical simulation. J. Neurosci. 15: 6592-6604.

Hennessey, J.W., Smotherman, W.P., and Levine, S. 1976. Conditioned taste aversion and the pituitary-adrenal system. Behav. Biol. 16: 413-424.

Hofer, M.A. and Sullivan, R.M. 2001. Toward a neurobiology of attachment. In Handbook of developmental cognitive neuroscience (eds. C.A. Nelson and M. Luciana), pp. 599-616. MIT Press, Cambridge, MA.

Hofer, M.A., Shair, H., and Singh, P. 1976. Evidence that maternal ventral skin substances promotes suckling in infant rats. Physiol. Behav. 17: 131-136.

Hoffmann, H., Molina, J.C., Kucharski, D., and Spear, N.E. 1987. Further examination of ontogenetic limitations on conditioned taste aversion. Dev. Psychobiol. 20: 455-463.

Hoffmann, H., Hunt, P., and Spear, N.E. 1990. Ontogenetic differences in the association of gustatory and tactile cues with lithium chloride and footshock. Behav. Neural Biol. 53: 441-450.

Holland, P.C. and Gallagher, M. 2004. Amygdala-frontal interactions and reward expectancy. Curr. Opin. Neurobiol. 14: 148-155.

Hunt, P.S., Spear, L.P., and Spear, N.E. 1991. An ontogenetic comparison of ethanol-mediated taste aversion learning and ethanol-induced hypothermia in preweanling rats. Behav. Neurosci. 105: 971-983.

Kadohisa, M. and Wilson, D.A. 2006. Separate encoding of identity and similarity of complex familiar odors in piriform cortex. Proc. Natl. Acad. Sci. 103: $15206-15211$.

Kehoe, P. and Blass, E.M. 1986. Conditioned aversion and their memories in 5-day-old rats during suckling. J. Exp. Psychol. Anim. Behav. Process. 12: 40-47.

Kesner, R.P., Berman, R.F., and Tardif, R. 1992. Place and taste aversion learning: Role of basal forebrain, parietal cortex, and amygdala. Brain Res. Bull. 29: 345-353.

Krettek, J.E. and Price, J.L. 1978. A description of the amygdaloid complex in the rat and cat with observations on intra-amygdaloid axonal connections. J. Comp. Neurol. 178: 255-280.

Kucharski, D. and Spear, N.E. 1984. Conditioning of aversion to an odor paired with peripheral shock in the developing rat. Dev. Psychobiol. 17: 465-479.

LeDoux, J.E. 2000. Emotion circuits in the brain. Annu. Rev. Neurosci. 23: $155-184$.

Leon, M. 1992. Neuroethology of olfactory preference development. J. Neurobiol. 23: 1557-1573.

Litaudon, P., Mouly, A., Sullivan, R., Gervais, R., and Cattarelli, M. 1997. Learning-induced changes in rat piriform cortex activity mapped using multisite recording with voltage sensitive dye. Eur. J. Neurosci. 9: 1593-1602.

Litaudon, P., Amat, C., Bertrand, B., Vigouroux, M., and Buonviso, N. 2003. Piriform cortex functional heterogeneity revealed by cellular responses to odours. Eur. J. Neurosci. 17: 2457-2461.

Luskin, M.B. and Price, J.L. 1983. The topographic organization of associational fibers on the olfactory system in the rat, including centrifugal fibers to the olfactory bulb. J. Comp. Neurol. 216: 264-291. 
Martin, L.T. and Alberts, J.R. 1979. Taste aversions to mother's milk: The age-related role of nursing in acquisition and expression of a learned association. J. Comp. Physiol. Psychol. 93: 430-445.

McDonald, A.J. 1998. Cortical pathways to the mammalian amygdala. Prog. Neurobiol. 55: 257-332.

McLean, J.H., Harley, C.W., Darby-King, A., and Yuan, Q. 1999. pCREB in the neonate rat olfactory bulb in selectively and transiently increased by odor preference conditioned training. Learn. Mem. 6: 608-618.

Melcer, T., Alberts, J.R., and Gubernick, D.J. 1985. Early weaning does not accelerate the expression of nursing-related taste aversion. Dev. Psychobiol. 18: 375-381.

Miller, J.S., Kelly, K.S., Neisewander, J.L., McCoy, D.F., and Bardo, M.T. 1990a. Conditioning of morphine-induced taste aversion and analgesia. Psychopharmacology 101: 472-480.

Miller, J.S., Molina, J.C., and Spear, N.E. 1990b. Ontogenentic differences in the expression of odor-aversion learning in 4- and 8-day-old rats. Dev. Psychobiol. 23: 319-330.

Molina, J.C., Hoffmann, H., and Spear, N.E. 1986. Conditioning of aversion to alcohol orosensory cues in 5- and 10-day rats: Subsequent reduction in alcohol ingestion. Dev. Psychobiol. 19: 175-183.

Moriceau, S. and Sullivan, R.M. 2004. Corticosterone influences on mammalian neonatal sensitive period leaning. Behav. Neurosci. 118: 274-281.

Moriceau, S. and Sullivan, R.M. 2006. Maternal presence serves to switch between learning fear and attraction in infancy. Nat. Neurosci. 9: 1004-1006.

Moriceau, S., Wilson, D.A., Levine, S., and Sullivan, R.M. 2006. Dual circuitry for odor-shock conditioning during infancy: Corticosterone switches fear and attraction via amygdala. J. Neurosci. 26: 6737-6748.

Morys, J., Berdel, B., Kowianski, P., Majak, K., Tarnawski, M., and Wisniewski, H.M. 1999. Relationship of calcium-binding protein containing neurons and projection neurons in the rat basolateral amygdala. Neurosci. Lett. 259: 91-94.

Mouly, A.M. and Gervais, R. 2002. Polysynaptic potentiation at different levels of rat olfactory pathways following learning. Learn. Mem. 9: 66-75.

Mouly, A.M., Fort, A., Ben-Boutayab, N., and Gervais, R. 2001. Olfactory learning induces differential long-lasting changes in rat central olfactory pathways. Neuroscience 102: 11-21.

Nachman, M. and Ashe, J.H. 1974. Effects of basolateral amygdala lesions on neophobia, learned taste aversions, and sodium appetite in rats. J. Comp. Physiol. Psychol. 87: 622-643.

Ottersen, O.P. 1982. Connections of the amygdala of the rat. IV: Corticoamygdaloid and intra-amygdaloid connections as studied with axonal transport of horseradish peroxidase. J. Comp. Neurol. 205: 30-48.

Otto, T., Cousens, G., and Herzog, C. 2000. Behavioral and neuropsychological foundations of olfactory fear conditioning. Behav. Brain Res. 110: 119-128.

Paxinos, G. and Watson, C. 1986. The rat brain in stereotaxic coordinates. Academic Press, San Diego, CA.

Pedersen, P.E., Williams, C.L., and Blass, E.M. 1982. Activation and odor conditioning of suckling behavior in 3-day-old albino rats. J. Exp. Psychol. Anim. Behav. Process. 8: 329-341.

Polan, H.J. and Hofer, M.A. 1999. Maternally directed orienting behaviors of newborn rats. Dev. Psychobiol. 34: 269-279.

Ponnusamy, R., Paulos, A.M., and Fanselow, M.S. 2007. Amygdaladependent and amygdala-independent pathways for contextual fear conditioning. Neuroscience 147: 919-927.

Richardson, R. and McNally, G.P. 2003. Effects of an odor paired with illness on startle, freezing, and analgesia in rats. Physiol. Behav. 78: 213-219.

Roth, T. and Sullivan, R.M. 2001. Endogenous opioids and their role in odor preference acquisition and consolidation following odor-shock conditioning in infant rats. Dev. Psychobiol. 39: 188-198.

Roth, T.L. and Sullivan, R.M. 2003. Consolidation and expression of a shock-induced odor preference in rat pups is facilitated by opioids. Physiol. Behav. 78: 135-142.

Roth, T.L. and Sullivan, R.M. 2005. Memory of early maltreatment: Neonatal behavioral and neural correlates of maternal maltreatment within the context of classical conditioning. Biol. Psychiatry 57: 823-831.

Roth, T., Moriceau, S., and Sullivan, R.M. 2006. Opioid modulation of Fos protein expression and olfactory circuitry plays a pivot role in what neonates remember. Learn. Mem. 13: 590-598.

Rudy, J.W. and Cheatle, M.D. 1977. Odor-aversion learning in neonatal rats. Science 198: 845-846.

Rudy, J.W. and Cheatle, M.D. 1983. Odor-aversion learning by rats following $\mathrm{LiCl}$ exposure: Ontogenetic influences. Dev. Psychobiol. 16: 13-22.

Sah, P., Faber, E.S., Lopez de Armentia, M., and Power, J. 2003. The amygdaloid complex: Anatomy and physiology. Physiol. Rev. 83: 803-834.

Sakai, N. and Yamamoto, T. 1999. Possible routs of visceral information in the rat brain in formation of conditioned taste aversion. Neurosci. Res. 35: 53-61.
Savander, V., Go, C.G., LeDoux, J.E., and Pitkanen, A. 1996. Intrinsic connections of the rat amygdaloid complex: Projections originating in the accessory basal nucleus. J. Comp. Neurol. 374: 291-313.

Sevelinges, Y., Gervais, R., Messaoudi, B., Granjon, L., and Mouly, A.M. 2004. Olfactory fear conditioning induces field potential potentiation in rat olfactory cortex and amygdala. Learn. Mem. 11: 761-769.

Sevelinges, Y., Moriceau, S., Holman, P., Miner, E., Muzny, K., Gervais, R., Mouly, A.M., and Sullivan, R.M. 2007. Enduring effects of infant memories: Infant odor-shock conditioning attenuates amygdala activity and adult fear conditioning. Biol. Psychiatry 62: 1070-1079.

Shionoya, K., Moriceau, S., Lunday, L., Miner, C., Roth, T.L., and Sullivan, R.M. 2006. Development switch in neural circuitry underlying odormalaise learning. Learn. Mem. 13: 801-808.

Smotherman, W.P. 1982. Odor aversion learning by the rat fetus. Physiol. Behav. 29: 769-771.

Smotherman, W.P. and Robinson, S.R. 1985. The rat fetus in its environment: Behavioral adjustments to novel, familiar, aversive, and conditioned stimuli presented in utero. Behav. Neurosci. 99: 521-530.

Smotherman, W.P. and Robinson, S.R. 1990. The prenatal origins of behavioral organization. Psychol. Sci. 1: 97-106.

Stehouwer, D.J. and Campbell, B.A. 1978. Habituation of the forelimbwithdrawal response in neonatal rats. J. Exp. Psychol. Anim. Behav. Process. 4: 104-119.

Stern, D.N., Fieve, R.R., Neff, N.H., and Costa, E. 1969. The effect of lithium chloride administration on brain and heart norepinephrine turnover rates. Psychopharmacologia 14: 315-322.

Stickrod, G., Kimble, D.P., and Smotherman, W.P. 1982. In utero taste/odor aversion conditioning in the rat. Physiol. Behav. 28: 5-7.

Sullivan, R.M. and Leon, M. 1986. Early olfactory learning induces an enhanced olfactory bulb responses in young rats. Brain Res. Dev. Brain Res. 27: 278-282.

Sullivan, R.M. and Wilson, D.A. 1995. Dissociation of behavior and neural correlates of early association learning. Dev. Psychobiol. 28: 213-219.

Sullivan, R.M., Hofer, M.A., and Brake, S.C. 1986. Olfactory-guided orientation in neonatal rats is enhanced by a conditioned change in behavior state. Dev. Psychobiol. 19: 615-623.

Sullivan, R.M., Wilson, D.A., Wong, R., Correa, A., and Leon, M. 1990. Modified behavioral olfactory bulb responses to maternal odor in preweanling rats. Brain Res. Dev. Brain Res. 53: 243-247.

Sullivan, R.M., Landers, M., Yeaman, B., and Wilson, D.A. 2000a. Good memories of bad events in infancy: Ontogeny of conditioned fear and the amygdala. Nature 407: 38-39.

Sullivan, R.M., Stackenwalt, G., Nasr, F., Lemon, C., and Wilson, D.A. $2000 \mathrm{~b}$. Association of an odor with activation of olfactory bulb noradrenergic $\beta$-receptors or locus coeruleus stimulation is sufficient to produce learning approach responses to that odor in neonatal rats. Behav. Neurosci. 114: 957-962.

Swanson, L.W. and Petrovich, G.D. 1998. What is the amygdala? Trends Neurosci. 21: 323-331.

Touzani, K. and Sclafani, A. 2005. Critical role of amygdala in flavor but not taste preference learning in rats. Eur. J. Neurosci. 22: 1767-1774.

Tronel, S. and Sara, S.J. 2002. Mapping of olfactory memory circuits: Region specific c-fos activation after odor-reward associative learning or after its retrieval. Learn. Mem. 9: 105-111.

Wilkins, E.E. and Bernstein, I.L. 2006. Conditioning method determines patterns of c-fos expression following novel taste-illness pairing. Behav. Brain Res. 169: 93-97.

Wilson, D.A. 1997. Bi-naral interactions in the rat piriform cortex. J. Neurophysiol. 78: 160-169.

Wilson, D.A. 2000. A comparison of odor receptive field plasticity in the rat olfactory bulb and anterior piriform cortex. J. Neurophysiol. 84: 3036-3042.

Wilson, D.A. and Stevenson, R.J. 2003. The fundamental role of memory in olfactory perception. Trends Neurosci. 26: 243-247.

Wilson, D.A., Sullivan, R.M., and Leon, M. 1987. Single-unit analyses of postnatal olfactory learning: Modified olfactory bulb output response patterns to learned attractive odors. J. Neurosci. 7: 3154-3162.

Wilson, D.A., Fletcher, M.L., and Sullivan, R.M. 2004. Acetylcholine and olfactory perceptual learning. Learn. Mem. 11: 28-34.

Woo, C.C., Oshita, M.H., and Leon, M. 1996. A learned odor response decreases the number of Fos-immunopositive granule cells in the olfactory bulb of young rats. Brain Res. 716: 149-156.

Yamamoto, T. and Fujimoto, Y. 1991. Brain mechanisms of taste aversion learning in the rat. Brain Res. Bull. 27: 403-406.

Yuan, Q., Harley, C.W., and McLean, J.H. 2003. Mitral cell $\beta_{1}$ and 5-HT $\mathrm{H}_{2 \mathrm{~A}}$ receptor co-localization and cAMP co-regulation: A new model of norepinephrineinduced learning in the olfactory bulb. Learn. Mem. 10: 5-15.

Received February 27, 2008; accepted in revised form November 13, 2008. 


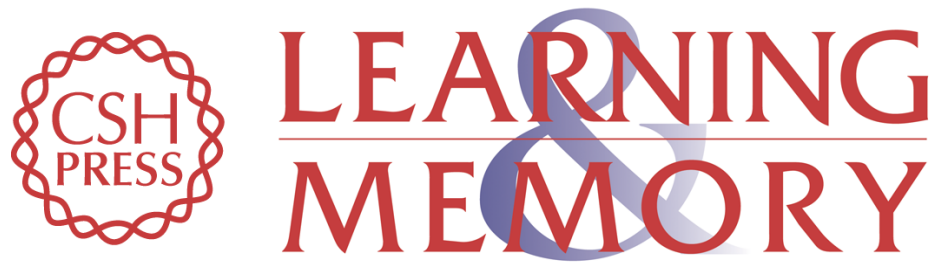

\section{Ontogeny of odor-LiCl vs. odor-shock learning: Similar behaviors but divergent ages of functional amygdala emergence}

Charlis Raineki, Kiseko Shionoya, Kristin Sander, et al.

Learn. Mem. 2009, 16:

Access the most recent version at doi:10.1101//m.977909

References This article cites 105 articles, 15 of which can be accessed free at: http://learnmem.cshlp.org/content/16/2/114.full.html\#ref-list-1

License

Email Alerting Receive free email alerts when new articles cite this article - sign up in the box at the Service top right corner of the article or click here. 